EVALUASI, 4 (1), Maret 2020, ISSN 2580-3387 (print) |

ISSN 2615-2886 (online)

Homepage : http://e-journal.staima-alhikam.ac.id/index.php/evaluasi

DOI : : http://doi.org/10.32478/evaluasi.v4i1.362

Article type : Original Research Article

\title{
HARD SKILLS DAN SOFT SKILLS: APA MEMBANGUN INOVASI GURU SEKOLAH ISLAM?
}

\author{
Masduki Asbari ${ }^{1 *}$, Choi Chi Hyun ${ }^{2}$, Laksmi Mayesti Wijayanti ${ }^{3}$, Evy Yanthy ${ }^{4}$, \\ , Miyv Fayzhall ${ }^{5}$, Firdaus Putra ${ }^{6}$, Winanti $^{7}$ \\ 1, 2, 3, 4, Universitas Pelita Harapan \\ 5, 6 STIE Insan Pembangunan \\ ${ }^{7}$ STMIK Insan Pembangunan
}

\begin{abstract}
This study aims to measure the effect of hard skills and soft skills on the innovation capabilities of Islamic school teachers in Jakarta and Tangerang which are mediated by organizational culture. Data collection is done by simple random sampling via electronic to the teacher population in Jakarta and Tangerang. The returned and valid questionnaire results were 667 samples. Data processing using SEM method with SmartPLS 3.0 software. The results of this study conclude that hard skills and soft skills have a positive and significant effect on the ability of teacher innovation, both directly and indirectly through mediating organizational culture. This new research proposes a model for building the innovation capability of Islamic school teachers among teachers in Jakarta and Tangerang through enhancing hard skills and soft skills with organizational culture as a mediator. This research can pave the way to improve teacher readiness in facing the era of education 4.0.
\end{abstract}

Keywords: Hard skills; education 4.0; organizational culture; soft skills; teacher innovation capability

\footnotetext{
*Corresponding author, email: kangmasduki.ssi@gmail.com

EVALUASI: Jurnal Manajemen Pendidikan Islam is licensed under

The CC BY License (https://creativecommons.org/licenses/by-sa/4.0/)
} 
EVALUASI, 4 (1), Maret 2020, ISSN 2580-3387 (print) |

ISSN 2615-2886 (online)

Homepage : http://e-journal.staima-alhikam.ac.id/index.php/evaluasi

DOI : : http://doi.org/10.32478/evaluasi.v4i1.362

Article type : Original Research Article

\begin{abstract}
Abstrak
Penelitian ini bertujuan untuk mengukur pengaruh hard skills dan soft skills terhadap kemampuan inovasi guru sekolah Islam di Jakarta dan Tangerang yang dimediasi oleh organizational culture. Pengumpulan data dilakukan dengan pengambilan sampel acak sederhana melalui elektronik ke populasi guru di Jakarta dan Tangerang. Hasil kuesioner yang dikembalikan dan valid adalah 667 sampel. Pemrosesan data menggunakan metode SEM dengan perangkat lunak SmartPLS 3.0. Hasil penelitian ini menyimpulkan bahwa hard skills dan soft skills berpengaruh positif dan signifikan terhadap kemampuan inovasi guru, baik secara langsung maupun tidak langsung melalui mediasi organizational culture. Penelitian baru ini mengusulkan sebuah model untuk membangun kemampuan inovasi guru sekolah Islam di antara para guru di Jakarta dan Tangerang melalui peningkatan hard skills dan soft skills dengan organizational culture sebagai mediator. Penelitian ini dapat membuka jalan untuk meningkatkan kesiapan guru dalam menghadapi era pendidikan 4.0.
\end{abstract}

Kata kunci: Hard skills; education 4.0; organizational culture; soft skills; teacher innovation capability

\title{
Pendahuluan
}

Perubahan dramatis yang datang dari industrial revolution 4.0 menjadi tantangan baru bagi dunia pendidikan. Revolusi industry ini mempersyaratkan kualitas sumber daya manusia yang lebih mumpuni, agile, adaptif dan responsive terhadap perubahan yang cepat. Dunia pendidikan menghadapi perubahan ekonomi, social, politik dan teknologi yang demikian cepat. Oleh karenanya, sekolah harus fleksibel untuk mampu beradaptasi dengan situasi dan konteks yang berubah. Sekolah dan lembaga pendidikan lainnya membutuhkan lingkungan yang terus tumbuh positif dan kondusif dalam kompetisi sumber daya manusia global. Oleh karena itu, tak bisa dipungkiri bahwa sekolah membutuhkan sinergi antara guru dan lingkungan kerja yang mampu melakukan perbaikan terus-menerus dalam inovasi dan performansi. Intinya adalah di era ekonomi pengetahuan ini muncul masyarakat pengetahuan yang membutuhkan inovasi dan 
EVALUASI, 4 (1), Maret 2020, ISSN 2580-3387 (print) |

ISSN 2615-2886 (online)

Homepage : http://e-journal.staima-alhikam.ac.id/index.php/evaluasi

DOI : : http://doi.org/10.32478/evaluasi.v4i1.362

Article type : Original Research Article

fleksibilitas sebagai energy untuk bertahan dari persaingan. Oleh karena itu, pembangunan strategis lembaga pendidikan di masa depan adalah pada peningkatan sumber daya pengetahuan, terutama guru, yang membuka ruang inovasi dan pertumbuhan.

Untuk memastikan bahwa lembaga pendidikan, khususnya sekolah bisa kompetitif dan adaptif, guru perlu diarahkan dan terlibat dalam memompa performansi sekolah. Guru harus berdaya dan memberdayakan. Alhasil, sekolah harus mewujud menjadi organizational culture yang sesungguhnya. Organizational culture yang memberdayakan guru sebagai salah satu unsur utama transformasi sekolah, sekaligus guru sebagai instrumen peradaban. Bentuk sekolah sebagai organizational culture sangat penting untuk lembaga pendidikan yang beroperasi di lingkungan dengan perubahan cepat dan tak terduga. Sehingga kecepatan respon atas perubahan menjadi syarat mutlak mencetak sumber daya manusia, siswa yang kompetitif dan memenangkan persaingan SDM global.

Pengetahuan individu guru dan sekolah menjadi modal intelektual yang dengan cepat menjadi icon baru yang menggambarkan nilai ekonomis sebuah sekolah. Inilah paradigma baru yang diadaptasi dari industrial revolution 4.0. Ketergantungan pada asset produktif tradisional seperti gedung, bangunan, tanah dan tangible asset lainnya tidak lagi menjadi sumbangan investasi utama masa depan. Aset produktif dan berkelanjutan di masa depan adalah aset intangible dalam bentuk pengetahuan yang melekat pada guru. Penelitian ini berupaya untuk memahami dan menjelaskan pengaruh hard skills dan soft skills guru terhadap teacher innovation capability mereka. Selanjutnya diukur juga pengaruh mediasi organizational culture terhadap hubungan antara hard skills, soft skills dan inovasi guru di Indonesia.

\section{Tinjauan Literatur dan Hipotesis Hard Skills}

Hard skills adalah salah satu jenis pengetahuan yang mudah didokumentasikan dan dibentuk $^{1}$, mudah diartikulasikan ${ }^{2}$ dan biasanya

\footnotetext{
${ }^{1}$ Borrego, G., Morán, A. L., Palacio, R. R., Vizcaíno, A., \& García, F. O. (2019). Towards a reduction in architectural knowledge vaporization during agile global software development. Information and Software Technology. doi:10.1016/j.infsof.2019.04.008
} 
EVALUASI, 4 (1), Maret 2020, ISSN 2580-3387 (print) |

ISSN 2615-2886 (online)

Homepage : http://e-journal.staima-alhikam.ac.id/index.php/evaluasi

DOI : : http://doi.org/10.32478/evaluasi.v4i1.362

Article type : Original Research Article

merupakan pengetahuan yang melekat pada sekolah. Selain itu, hard skills dapat dibuat, ditulis dan ditransfer di antara unit kegiatan sekolah ${ }^{3}$. Transfer hard skills di antara guru lebih mudah didorong oleh mekanisme dan budaya sekolah yang kondusif.

Hard skills dapat digambarkan secara umum dan juga didasarkan pada konteks khusus dimana keterampilan ini digunakan. Rainsbury et al ${ }^{4}$ mendefinisikan hard skill keterampilan yang berkaitan dengan aspek teknis untuk melakukan beberapa tugas dalam pekerjaan. Karena itu, hard skills pada dasarnya bersifat kognitif dan dipengaruhi oleh intelectual quotient (IQ) ${ }^{5}$. Secara kontekstual, beberapa peneliti menggunakan konsep hard skill pada khususnya keadaan manajemen. Para peneliti umumnya merujuk pada hard skills dalam konteks manajemen proyek sebagai proses, prosedur, alat, dan teknik 6 .

Hard skill menggambarkan perilaku dan keterampilan yang dapat dilihat di mata (eksplisit). Hard skill adalah keterampilan yang dapat menghasilkan sesuatu yang terlihat dan langsung. Keterampilan keras dapat dinilai dari tes teknis atau tes praktis. Unsur-unsur keterampilan keras dapat kita lihat dari kecerdasan quotient thinking yang memiliki indikator untuk menghitung, menganalisis, merancang, wawasan dan pengetahuan yang luas, pembuatan model dan kritis. Hard skill terkait dengan penguasaan ilmu pengetahuan, teknologi dan keterampilan teknis terkait dengan bagian pengetahuan. Seorang guru harus memiliki keterampilan dalam membuka pelajaran, mengelola kelas, merancang diskusi kelompok, mengatur ruangan,

${ }^{2}$ Haamann, T., \& Basten, D. (2018). The role of information technology in bridging the knowing-doing gap: an exploratory case study on knowledge application. Journal of Knowledge Management. doi:10.1108/jkm-01-2018-0030

${ }^{3}$ Lombardi, R. (2019). Knowledge transfer and organizational performance and business process: past, present and future researches. Business Process Management Journal, 25(1), 2-9. doi:10.1108/bpmj-02-2019-368

${ }^{4}$ Rainsbury, E., Hodges, D., Burchell, N. \& Lay, M. C. (2002). Ranking workplace competencies: Student and graduate perceptions. Asia-Pacific Journal of Cooperative Education, 3(2), 8-18. https://hdl.handle.net/10289/3219

5 Rainsbury, E., Hodges, D., Burchell, N. \& Lay, M. C. (2002). Ranking workplace competencies: Student and graduate perceptions. Asia-Pacific Journal of Cooperative Education, 3(2), 8-18. https://hdl.handle.net/10289/3219

${ }^{6}$ Azim, S., Gale, A., Lawlor-Wright, T., Kirkham, R., Khan, A., \& Alam, M. (2010). The importance of soft skills in complex projects. International Journal of Managing Projects in Business, 3(3), 387-401. doi:10.1108/17538371011056048 
EVALUASI, 4 (1), Maret 2020, ISSN 2580-3387 (print) |

ISSN 2615-2886 (online)

Homepage : http://e-journal.staima-alhikam.ac.id/index.php/evaluasi

DOI : : http://doi.org/10.32478/evaluasi.v4i1.362

Article type : Original Research Article

dan menulis yang baik ${ }^{7}$. Hard skill adalah keterampilan yang relatif lebih mudah untuk diukur. Widoyoko membedakan antara hard skill menjadi dua, yaitu keterampilan akademik dan kejuruan mereka. Keterampilan akademik adalah kemampuan untuk menguasai berbagai konsep dalam bidang ilmu yang dipelajari, seperti keterampilan untuk mendefinisikan, menghitung, menjelaskan, menggambarkan, mengelompokkan, mengidentifikasi, menggambarkan, memprediksi, menganalisis, membandingkan, membedakan, membedakan, dan menarik kesimpulan dari suatu berbagai konsep, data dan fakta-fakta terkait mata pelajaran ${ }^{8}$.

\section{Soft Skills}

Knowledge diklasifikasikan menjadi dua jenis meliputi: soft skills dan hard skills ${ }^{9}$. Definisi soft skills adalah pengetahuan yang masih berada dalam benak manusia dan bersifat sangat personal ${ }^{10}$, sulit dirumuskan dan dibagi secara natural ${ }^{11}$ sehingga dalam transformasinya membutuhkan interaksi personal $^{12}$. Soft skills ini berada dan berakar di dalam tindakan maupun pengalaman seseorang, termasuk idealisme, nilai-nilai, maupun emosionalnya ${ }^{13}$.

Berdasarkan pengertiannya, maka soft skills dikategorikan sebagai personal knowledge atau dengan kata lain pengetahuan yang diperoleh

\footnotetext{
${ }^{7}$ Muqowim (2012). Pengembangan Soft Skills Guru. Yogyakarta: Pedagogia

${ }^{8}$ Widoyoko, E.P. (2009). Evaluasi Program Pembelajaran Panduan Praktis bagi Pendidik dan Calon Pendidik. Yogyakarta: Pustaka

${ }^{9}$ Polanyi, M. (1966). The Tacit dimension. New York: Doubleday \& Co.

${ }^{10}$ Holford, W.D. (2018). The future of human creative knowledge work within the digital economy. Futures. doi:10.1016/j.futures.2018.10.002

${ }^{11}$ Deranek, K., McLeod, A., \& Schmidt, E. (2017). ERP Simulation Effects on Knowledge and Attitudes of Experienced Users. Journal of Computer Information Systems, 1-11. doi:10.1080/08874417.2017.1373610

${ }^{12}$ Lee, Peter. (2019). Soft skills and University-Industry Technology Transfer. Research Handbook on Intellectual Property and Technology Transfer (2019, Forthcoming); UC Davis Legal Studies Research Paper Forthcoming. doi: http://dx.doi.org/10.2139/ssrn.3417933

${ }^{13}$ Boske, C. and Osanloo, A. (2015), "Conclusion - Preparing all School Community Leaders to Live their Work", Living the Work: Promoting Social Justice and Equity Work in Schools around the World (Advances in Educational Administration, Vol. 23), Emerald Group Publishing Limited, pp. 405-426. https://doi.org/10.1108/S1479$\underline{366020140000023032}$
} 
EVALUASI, 4 (1), Maret 2020, ISSN 2580-3387 (print) |

ISSN 2615-2886 (online)

Homepage : http://e-journal.staima-alhikam.ac.id/index.php/evaluasi

DOI : : http://doi.org/10.32478/evaluasi.v4i1.362

Article type : Original Research Article

dari individu atau perorangan ${ }^{14}$. Pengalaman yang diperoleh tiap guru tentunya berbeda-beda berdasarkan situasi dan kondisi yang tidak dapat diprediksi. Soft skills sifatnya tidak mudah diartikulasikan dan dikonversi menjadi hard skills ${ }^{15}$. Walaupun demikian, soft skills bisa diberdayakan dengan proses spiralisasi pengetahuan atau SECI Model ${ }^{16}$.

Setiap lembaga pendidikan sekolah harus memanfaatkan soft skills gurunya dengan mendorong untuk berbagi pengetahuan dan terus belajar. Lembaga pendidikan sekolah seperti ini akan menjadi lebih kreatif, inovatif dan memimpin di era education 4.0. Sekolah dapat memfasilitasi pengelolaan dan penggunaan pengetahuan tacit yang berada di luar kesadaran yang tersimpan di bawah pikiran bawah sadar setiap guru dengan pendekatan embedding dan sharing ${ }^{17}$.

\section{Organizational Culture}

Organizational culture yang baik akan lebih tahan terhadap krisis ${ }^{18}$. Dimensi seperti keinginan, disiplin, pengambilan keputusan, dan kesejajaran disajikan sebagai elemen penting pembelajaran organisasi ${ }^{19}$. Organizational culture juga merupakan indikator kinerja yang penting untuk mengevaluasi

${ }^{14}$ Stewart, C., Schiavon, L.M. and Bellotto, M.L. (2017) Knowledge, nutrition and coaching pedagogy: a perspective from female Brazilian Olympic gymnasts, Sport, Education and Society, 22(4): 511-527, DOI: 10.1080/13573322.2015.1046428

${ }^{15}$ Mohajan, Haradhan (2016): Sharing of Soft skills in Organizations: A Review. Published in: American Journal of Computer Science and Engineering, Vol. 3, No. 2 (1 July 2016): pp. 6-19. https://mpra.ub.uni-muenchen.de/id/eprint/82958

${ }^{16} \mathrm{Li}, \mathrm{M} ., \mathrm{Liu}, \mathrm{H}$. and Zhou, J. (2018), "G-SECI model-based knowledge creation for CoPS innovation: the role of grey knowledge", Journal of Knowledge Management, Vol. 22 No. 4, pp. 887-911. https://doi.org/10.1108/JKM-10-2016-0458

${ }^{17} \mathrm{Ma}$, Q., Mayfield, M. and Mayfield, J. (2018), "Keep them on-board! How organizations can develop employee embeddedness to increase employee retention", Development and Learning in Organizations, Vol. 32 No. 4, pp. 5-9. https://doi.org/10.1108/DLO-11-20170094

${ }^{18}$ Starbuck, W. (2017), "Organizational culture and unlearning", The Learning Organization, Vol. 24 No. 1, pp. 30-38. https://doi.org/10.1108/TLO-11-2016-0073

${ }_{19}$ Wetzel R., Tint B. (2019) Using Applied Improvisation for Organizational culture in the Red Cross Red Crescent Climate Centre. In: Antonacopoulou E., Taylor S. (eds) Sensuous Learning for Practical Judgment in Professional Practice. Palgrave Studies in Business, Arts and Humanities. Palgrave Macmillan, Cham. https://doi.org/10.1007/978-3-31999049-1_3 
EVALUASI, 4 (1), Maret 2020, ISSN 2580-3387 (print) |

ISSN 2615-2886 (online)

Homepage : http://e-journal.staima-alhikam.ac.id/index.php/evaluasi

DOI : : http://doi.org/10.32478/evaluasi.v4i1.362

Article type : Original Research Article

kinerja organisasi secara keseluruhan ${ }^{20}$ yang mampu membantu membangun sumber daya pengetahuan yang diperlukan dan mempertahankan pertumbuhan serta kelangsungan sekolah. Kemampuan akses terhadap pengetahuan adalah factor pembeda antar sekolah yang satu dengan sekolah yang lainnya. Kesuksesan strategi lembaga pendidikan sekolah sangat signifikan berkaitan dengan basis pengetahuan yang kokoh dan dimiliki oleh setiap insan lembaga pendidikan sekolah.

\section{Teacher Innovation Capability}

Era indusry 4.0 saat ini membutuhkan teacher innovation capability sebagai keunggulan kompetitif sekolah ${ }^{21}$, competitive strategy ${ }^{22}$, kunci untuk menghadapi era industry 4.0 bagian dari kualitas manajemen abad ke-21 ${ }^{23}$, banyak memberi keuntungan terhadap bisnis ${ }^{24}$. Kemampuan inovasi diakui sebagai salah satu sumber daya internal paling penting yang dapat menghasilkan kinerja lembaga pendidikan sekolah yang unggul ${ }^{25}$. Inovasi merupakan aspek penting dari pendidikan yang berkualitas ${ }^{26}$.

${ }^{20}$ Qi, C. and Chau, P.Y.K. (2018) Will enterprise social networking systems promote knowledge management and organizational culture? An empirical study, Journal of Organizational Computing and Electronic Commerce, 28:1, 31-57, DOI: $\underline{10.1080 / 10919392.2018 .1407081}$

${ }^{21}$ Malik, A. (2019). Creating competitive advantage through source basic capital strategic humanity in the industrial age 4.0. International Research Journal of Advanced Engineering and Science 4(1): 209-215. www.irjaes.com/pdf/V4N1Y18-IRJAES/IRJAESV4N1P195Y19.pdf

${ }^{22}$ Culot, G., Orzes, G., \& Sartor, M. (2019). Integration and scale in the context of Industry 4.0: the evolving shapes of manufacturing value chains. IEEE Engineering Management Review, 1-1. doi:10.1109/emr.2019.2900652

${ }^{23}$ Gunasekaran, A., Subramanian, N., \& Ngai, E. (2018). Quality Management in the 21st Century Enterprises: Research pathway towards Industry 4.0. International Journal of Production Economics. doi:10.1016/j.ijpe.2018.09.005

${ }^{24}$ Zambon, I., Cecchini, M., Egidi, G., Saporito, M. G., \& Colantoni, A. (2019). Revolution 4.0: Industry vs. Agriculture in a Future Development for SMEs. Processes, 7(1), 36. doi:10.3390/pr7010036

${ }^{25}$ Zouaghi, F., Sánchez, M., \& Martínez, M. G. (2018). Did the global financial crisis impact firms' innovation performance? The role of internal and external knowledge capabilities in high and low tech industries. Technological Forecasting and Social Change. 132: 92-104. doi:10.1016/j.techfore.2018.01.011

${ }^{26}$ Klaeijsen, A., Vermeulen, M., \& Martens, R. (2017). Teachers' Innovative Behaviour: The Importance of Basic Psychological Need Satisfaction, Intrinsic Motivation, and 
EVALUASI, 4 (1), Maret 2020, ISSN 2580-3387 (print) |

ISSN 2615-2886 (online)

Homepage : http://e-journal.staima-alhikam.ac.id/index.php/evaluasi

DOI : : http://doi.org/10.32478/evaluasi.v4i1.362

Article type : Original Research Article

\section{Pengaruh Hard skills dan Soft Skills terhadap Teacher Innovation Capability}

Di era industry 4.0 saat ini, ditandai dengan kompetisi yang semakin ketat, keberlanjutan tetap menjadi perhatian dan masalah penting. Teacher innovation capability menjadi pendorong keberlanjutan bisnis. Kinerja ini bergantung pada budaya pengetahuan yang tertanan dalam organisasi. Pengetahuan yang terdiri atas tacit dan hard skills. Banyak peneliti membahas teacher innovation capability yang berkesimpulan bahwa innovation dipengaruhi oleh leadership ${ }^{27}$, employee involvement climate ${ }^{28}$, knowledge sharing ${ }^{29}$, knowledge search ${ }^{30}$, collaborative culture ${ }^{31}$ dan knowledge process ${ }^{32}$. Penelitian ini, hendak menguji pengaruh hard skills dan soft skills terhadap teacher innovation capability guru di lembaga pendidikan sekolah dalam rangka menyongsong industrial revolution 4.0. Peneliti sebelumnya telah membuktikan pengaruh positif dan signifikan hard skills

Occupational Self-Efficacy. Scandinavian Journal of Educational Research, 62(5), 769 782. doi:10.1080/00313831.2017.1306803

${ }^{27}$ Samsir, S. (2018), The effect of leadership orientation on innovation and its relationship with competitive advantages of small and medium enterprises in Indonesia, International Journal of Law and Management, Vol. 60 No. 2, pp. 530-542. https://doi.org/10.1108/IJLMA-01-2017-0005

${ }^{28}$ Naqshbandi, M., Tabche, I. and Choudhary, N. (2019), Managing open innovation: The roles of empowering leadership and employee involvement climate, Management Decision, Vol. 57 No. 3, pp. 703-723. https://doi.org/10.1108/MD-07-2017-0660

${ }^{29} \mathrm{Kim}$, N. and Shim, C. (2018). Social capital, knowledge sharing and innovation of small- and medium-sized enterprises in a tourism cluster. International Journal of Contemporary Hospitality Management, Vol. 30 No. 6, pp. 2417-2437. https://doi.org/10.1108/IJCHM07-2016-0392

${ }^{30}$ Wang, C., Chen, M. and Chang, C. (2019), "The double-edged effect of knowledge search on innovation generations", European Journal of Innovation Management, Vol. ahead-ofprint No. ahead-of-print. https://doi.org/10.1108/EJIM-04-2018-0072

${ }^{31}$ Yang, Z., Nguyen, V. and Le, P. (2018), Knowledge sharing serves as a mediator between collaborative culture and teacher innovation capability: an empirical research, Journal of Business \& Industrial Marketing, Vol. 33 No. 7, pp. 958-969. https://doi.org/10.1108/JBIM-10-2017-0245

${ }^{32}$ Imran, M., Ilyas, M., Aslam, U. and Fatima, T. (2018), "Knowledge processes and firm performance: the mediating effect of employee creativity", Journal of Organizational Change Management, Vol. 31 No. 3, pp. 512-531. https://doi.org/10.1108/JOCM-10-2016$\underline{0202}$ 
EVALUASI, 4 (1), Maret 2020, ISSN 2580-3387 (print) |

ISSN 2615-2886 (online)

Homepage : http://e-journal.staima-alhikam.ac.id/index.php/evaluasi

DOI : : http://doi.org/10.32478/evaluasi.v4i1.362

Article type : Original Research Article

dan soft skills terhadap teacher innovation capability ${ }^{33}$. Lebih khusus, banyak peneliti menyimpulkan bahwa soft skills berpengaruh positif dan signifikan terhadap teacher innovation capability ${ }^{34}$ (Perez-Luno et al, 2018). Kesemuanya dalam lingkup organisasi bisnis. Namun demikian, ada peneliti yang menyebutkan bahwa formal \& informal learning mempengaruhi teacher innovation capability guru di sekolah ${ }^{35}$. Berdasarkan literature di atas, maka disusun hipotesis sebagai berikut:

$\mathrm{H}^{1}$ : Hard skills berpengaruh langsung terhadap teacher innovation capability $\mathrm{H}^{2}$ : Soft skills berpengaruh langsung terhadap teacher innovation capability

Pengaruh Hard skills dan Soft Skills terhadap Organizational Culture

Learning organization menjadi salah satu strategi bagi organisasi untuk mempelajari dinamika lingkungan usahanya ${ }^{36}$. Sekolah dengan rutinitas belajar yang terkelola akan menghasilkan kumpulan individu yang knowledgeable, baik hard skills maupun soft skills ${ }^{37}$. Sebagian peneliti menyimpulan bahwa organizational culture dipengaruhi oleh collaborative culture dan knowledge sharing ${ }^{38}$. Soft skills ditemukan menjadi predictor

${ }^{33}$ Ganguly, A., Talukdar, A. and Chatterjee, D. (2019), "Evaluating the role of social capital, soft skills sharing, knowledge quality and reciprocity in determining teacher innovation capability of an organization", Journal of Knowledge Management, Vol. 23 No. 6, pp. 1105-1135. https://doi.org/10.1108/JKM-03-2018-0190

${ }^{34}$ Pérez-Luño, A., Alegre, J., \& Valle-Cabrera, R. (2018). The role of soft skills in connecting knowledge exchange and combination with innovation. Technology Analysis \& Strategic Management, 1-13. doi:10.1080/09537325.2018.1492712

${ }^{35}$ Lecat, A., Beausaert, S. \& Raemdonck, I. (2018). On the Relation Between Teachers' (In)formal Learning and Innovative Working Behavior: the Mediating Role of Employability. Vocations and Learning 11, 529-554. doi:10.1007/s12186-018-9199-x

${ }^{36}$ Zhu, Q., Krikke, H. and Caniëls, M. (2018), Supply chain integration: value creation through managing inter-organizational culture. International Journal of Operations \& Production Management. 38(1): 211-229. https://doi.org/10.1108/IJOPM-06-2015-0372

${ }^{37}$ Hussain, S. T., Lei, S., Akram, T., Haider, M. J., Hussain, S. H., \& Ali, M. (2018). Kurt Lewin's change model: A critical review of the role of leadership and employee involvement in organizational change. Journal of Innovation \& Knowledge, 3(3), 123-127. doi:10.1016/j.jik.2016.07.002

${ }^{38}$ Nugroho, M. (2018), "The effects of collaborative cultures and knowledge sharing on organizational culture", Journal of Organizational Change Management, Vol. 31 No. 5, pp. 1138-1152. https://doi.org/10.1108/JOCM-10-2017-0385 
EVALUASI, 4 (1), Maret 2020, ISSN 2580-3387 (print) I

ISSN 2615-2886 (online)

Homepage : http://e-journal.staima-alhikam.ac.id/index.php/evaluasi

DOI : : http://doi.org/10.32478/evaluasi.v4i1.362

Article type : Original Research Article

yang sangat signifikan bagi pengembangan organizational culture ${ }^{39}$. Berdasarkan literature di atas, maka hipotesis yang akan diuji adalah sebagai berikut:

$\mathrm{H}^{3}$ : Hard skills berpengaruh langsung terhadap organizational culture

$\mathrm{H}^{4}$ : Soft skills berpengaruh langsung terhadap organizational culture

\section{Pengaruh Organizational Culture terhadap Teacher Innovation Capability}

Penciptaan pengetahuan yang dikondisikan oleh organizational culture akan memicu dan memacu teacher innovation capability dan kinerja organisasi ${ }^{40}$. Inovasi sekolah akan berkesinambungan ketika didasari oleh budaya belajar yang memberi nilai tambah. Budaya belajar inilah yang menjadikan semua guru berinteraksi satu sama lain sehingga pengetahuan mereka saat ini dan pengetahuan baru yang diperoleh dapat secara efektif ditransfer, dipertukarkan dan digabungkan menjadi kecerdasan dan pengetahuan sekolah ${ }^{41}$. Lingkungan organisasi yang memberikan kegembiraan dalam bekerja merupakan factor penting dalam menciptakan teacher innovation capability anggota organisasi ${ }^{42}$. Selanjutnya, berdasarkan literature di atas, hipotesis yang akan diuji adalah sebagai berikut:

$\mathrm{H}^{5}$ : Organizational culture berpengaruh langsung terhadap teacher innovation capability

Pengaruh Mediasi Organizational Culture terhadap hubungan Hard Skills,

39 Muthuveloo, R., Shanmugam, N., \& Teoh, A. P. (2017). The impact of soft skills management on organizational performance: Evidence from Malaysia. Asia Pacific Management Review, 22(4), 192-201. doi:10.1016/j.apmrv.2017.07.010

40 Asbari, M., Santoso, P., \& Purwanto, A. (2019). Pengaruh Iklim Organisasi dan Kepemimpinan Transformasional Terhadap Produktivitas Kerja Inovatif Pada Industri Manufaktur di Pati Jawa Tengah. Jurnal Produktivitas Universitas Muhammadiyah Pontianak: 7(1 2020): 62-69. DOI : 10.29406/jpr.v7i1.1797

${ }^{41}$ Chang, C. and Lin, T. (2015), "The role of organizational culture in the knowledge management process", Journal of Knowledge Management, Vol. 19 No. 3, pp. 433-455. https://doi.org/10.1108/JKM-08-2014-0353

42 Bani-Melhem, S., Zeffane, R. and Albaity, M. (2018), "Determinants of employees' innovative behavior", International Journal of Contemporary Hospitality Management, Vol. 30 No. 3, pp. 1601-1620. https://doi.org/10.1108/IJCHM-02-2017-0079 
EVALUASI, 4 (1), Maret 2020, ISSN 2580-3387 (print) |

ISSN 2615-2886 (online)

Homepage : http://e-journal.staima-alhikam.ac.id/index.php/evaluasi

DOI : : http://doi.org/10.32478/evaluasi.v4i1.362

Article type : Original Research Article

Soft Skills dan Teacher Innovation Capability

Honeycutt (2000) ${ }^{43}$ menjelaskan bahwa manajemen pengetahuan adalah disiplin yang memperlakukan modal intelektual dari aset yang dikelola. Karena, konsep manajemen pengetahuan pada dasarnya berkembang dari kenyataan bahwa di masa sekarang dan masa depan, aset utama organisasi untuk dapat bersaing adalah aset intelektual atau pengetahuan, bukan aset fisik. Secara umum, manajemen pengetahuan yang dilakukan oleh organizational culture adalah teknik atau cara untuk mengelola pengetahuan dalam organisasi untuk menciptakan nilai dan meningkatkan keunggulan kompetitif. Organizational culture sebagai variabel mediasi, memainkan peran antara hard skills, soft skills dan inovasi organisasi. Selain itu, proses ini telah dianggap sebagai sistem di mana pengetahuan dan keterampilan merupakan input, organizational culture adalah proses utama, dan inovasi organisasi adalah output penting ${ }^{44}$.

Selanjutnya, berdasarkan literature di atas, hipotesis yang akan diuji adalah sebagai berikut:

$\mathrm{H}^{6}$ : Hard skills berpengaruh tidak langsung terhadap teacher innovation capability melalui mediasi organizational culture

$\mathrm{H}^{7}$ : Soft skills berpengaruh tidak langsung terhadap teacher innovation capability melalui mediasi organizational culture

43 Honeycutt, Jerry. (2000). Knowledge Management Strategies: Strategi Manajemen Pengetahuan. Jakarta : PT. Alex Media Komputindo

44 Nouri, B.A., \& Ghorbani, R. (2017). The Effect of Knowledge Management on Organizational Innovation with the Mediating Role of Organizational culture (Case Study : Agricultural Bank in Iran). Journal of Applied Economics and Business Research JAEBR, 7(3): 194-211. https://www.semanticscholar.org/paper/The-Effect-of-KnowledgeManagement-on-Innovation-of-NouriGhorbani/fb9eb1df37e4a47c9b3ac2bbf0bbc4f4907b80a2 
EVALUASI, 4 (1), Maret 2020, ISSN 2580-3387 (print) |

ISSN 2615-2886 (online)

Homepage : http://e-journal.staima-alhikam.ac.id/index.php/evaluasi

DOI : $\quad:$ http://doi.org/10.32478/evaluasi.v4i1.362

Article type : Original Research Article

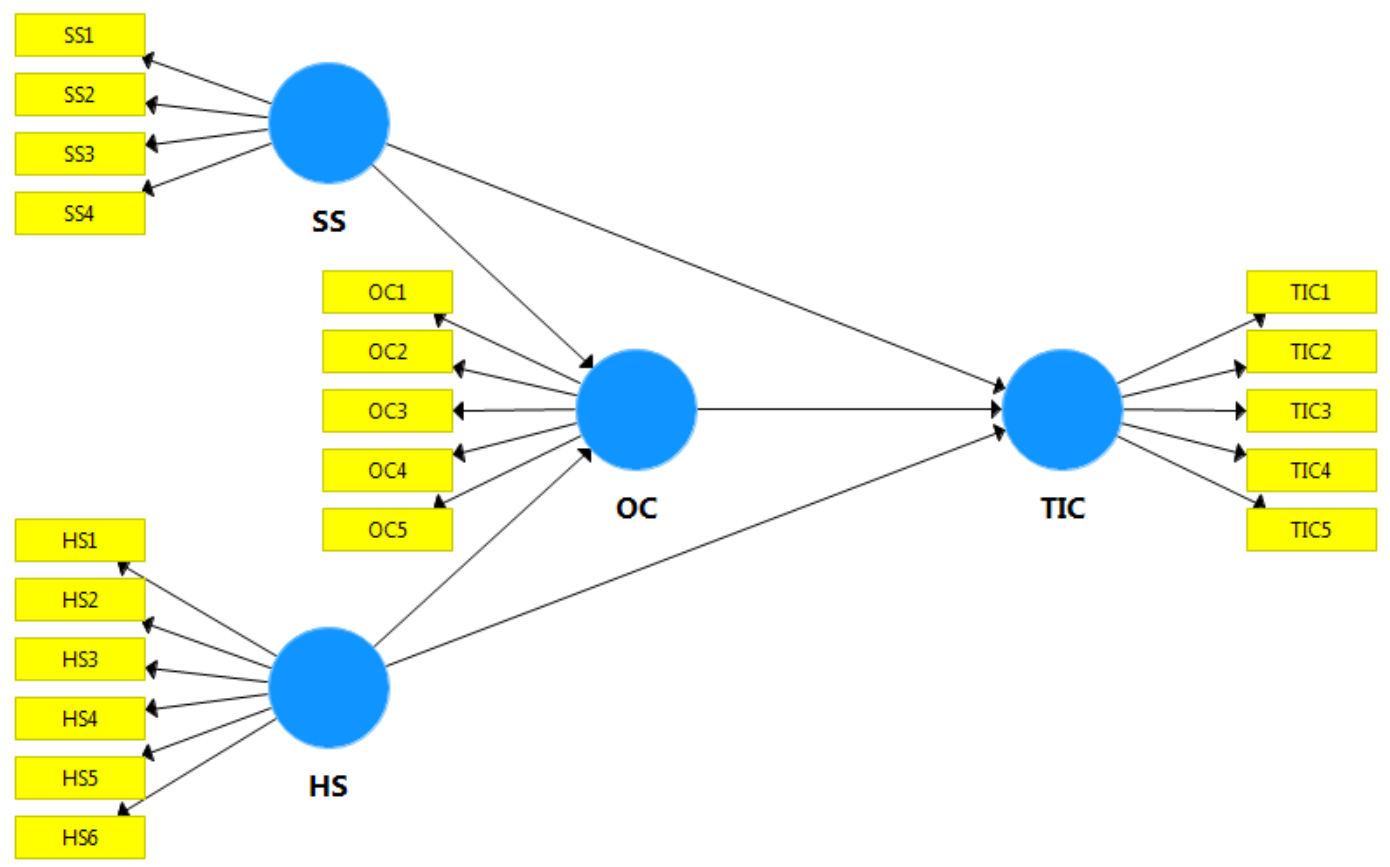

Gambar 1. Model Penelitian

\section{Metode Penelitian}

\section{Definisi Operasional Variabel dan Indikator}

Metode yang digunakan dalam penelitian ini adalah metode kuantitatif. Dilakukan pengumpulan data dengan mengedarkan angket kepada seluruh guru lembaga pendidikan sekolah. Instrumen yang digunakan untuk mengukur hard skills diadaptasi dari Hendarman \& Cantner ${ }^{45}$ dengan menggunakan 6 items. Soft skills diadaptasi juga dari Hendarman \& Cantner dengan menggunakan 4 items. Organizational culture diukur dari instrument

45 Hendarman, A. F., \& Cantner, U. (2017). Soft skills, hard skills, and individual innovativeness. Eurasian Business Review, 8(2), 139-169. doi:10.1007/s40821-017-00766 
EVALUASI, 4 (1), Maret 2020, ISSN 2580-3387 (print) |

ISSN 2615-2886 (online)

Homepage : http://e-journal.staima-alhikam.ac.id/index.php/evaluasi

DOI : $\quad$ http://doi.org/10.32478/evaluasi.v4i1.362

Article type : Original Research Article

yang diadaptasi dari Jiménez-Jiménez and Sanz-Valle ${ }^{46}$ dengan menggunakan 5 items. Teacher innovation capability diadaptasi dari Lee \& $\mathrm{Choi}^{47}$ dengan menggunakan 5 items. Angket didesain tertutup kecuali untuk pertanyaan/pernyataan mengenai identitas responden yang berupa angket semi terbuka. Tiap item pertanyaan/pernyataan tertutup diberikan lima opsi jawaban, yaitu: sangat setuju (SS) skor 5, setuju (S) skor 4, kurang setuju (KS) skor 3, tidak setuju (TS) skor 2, dan sangat tidak setuju (STS) skor 1. Metode untuk mengolah data adalah dengan PLS dan menggunakan software SmartPLS versi 3.0 sebagai toolnya.

\section{Populasi dan Sampel}

Populasi dalam penelitian ini adalah guru sekolah Islam di Jakarta dan Tangerang yang jumlahnya belum teridentifikasi secara pasti. Kuesioner disebarkan secara elektronik dengan teknik simple random sampling. Hasil kuesioner yang kembali sebanyak 674 dan yang valid adalah 667 sampel. Jadi $98.96 \%$ yang valid dari jumlah kuesioner yang terkumpul.

46 Jiménez-Jiménez, D., \& Sanz-Valle, R. (2011). Innovation, organizational culture, and performance. Journal of Business Research, 64(4), 408-417. doi:10.1016/j.jbusres.2010.09.010

47 Lee, H. and Choi, B. (2003). Knowledge Management Enablers, Processes, and Organizational Performance: An Integrative View and Empirical Examination. (2003). Journal of Management Information Systems, 20(1), 179-228. doi:10.1080/07421222.2003.11045756 
EVALUASI, 4 (1), Maret 2020, ISSN 2580-3387 (print) |

ISSN 2615-2886 (online)

Homepage : http://e-journal.staima-alhikam.ac.id/index.php/evaluasi

DOI : : http://doi.org/10.32478/evaluasi.v4i1.362

Article type : Original Research Article

\section{Pembahasan}

\section{Deskripsi Sampel}

Tabel 1. Informasi deskriptif sampel

\begin{tabular}{llcc}
\hline \multicolumn{1}{c}{ Kriteria } & & Jumlah & $\%$ \\
\hline Usia (per Oktober 2019) & $<30$ tahun & 136 & $20.41 \%$ \\
& $30-40$ tahun & 311 & $46.60 \%$ \\
& $>40$ tahun & 220 & $32.99 \%$ \\
\hline Status guru & Public (ASN) & 207 & $31.07 \%$ \\
& Private (Swasta) & 460 & $68.93 \%$ \\
\hline Masa kerja sebagai guru & $<5$ tahun & 211 & $31.66 \%$ \\
& $5-10$ tahun & 324 & $48.52 \%$ \\
& $>10$ tahun & 132 & $19.82 \%$ \\
\hline ljazah tertinggi & $<$ S1 & 53 & $7.99 \%$ \\
& $\geq$ S1 & 614 & $92.01 \%$ \\
\hline
\end{tabular}

Hasil Uji Validitas dan Reliabilitas Indikator Penelitian

Tahap pengujian model pengukuran meliputi pengujian convergent validity, discriminant validity dan composite reliability. Hasil analisis PLS dapat digunakan untuk menguji hipotesis penelitian jika seluruh indikator dalam model PLS telah memenuhi syarat validitas konvergen, validitas deskriminan dan uji reliabilitas.

\section{Pengujian Validitas Konvergen}

Uji validitas konvergen dilakukan dengan melihat nilai loading factor masing-masing indikator terhadap konstruknya. Pada sebagian besar referensi, bobot faktor sebesar 0.5 atau lebih dianggap memiliki validasi yang 
EVALUASI, 4 (1), Maret 2020, ISSN 2580-3387 (print) I

ISSN 2615-2886 (online)

Homepage : http://e-journal.staima-alhikam.ac.id/index.php/evaluasi

DOI : $\quad$ http://doi.org/10.32478/evaluasi.v4i1.362

Article type : Original Research Article

cukup kuat untuk menjelaskan konstruk laten ${ }^{48}$. Pada penelitian ini batas minimal besarnya loading factor yang diterima adalah 0.5 , dengan syarat nilai AVE setiap konstruk $>0.5^{49}$.

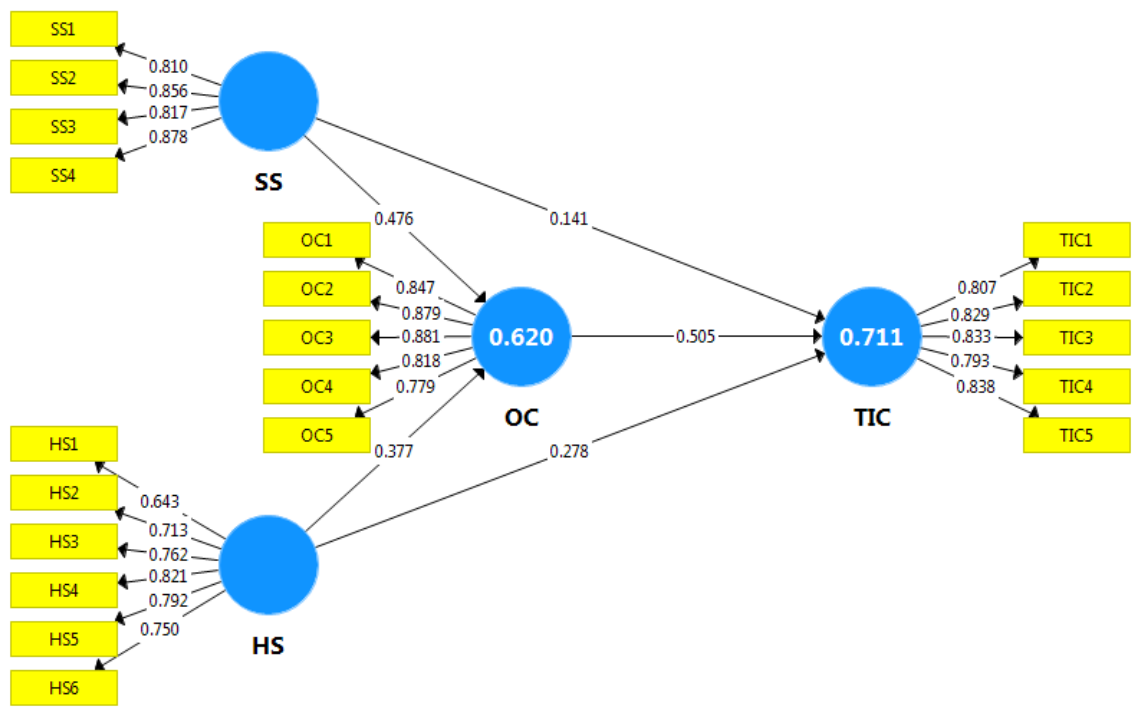

Gambar 2. Estimasi model valid

Berdasarkan hasil estimasi model PLS pada gambar di atas, seluruh indikator telah memiliki nilai loading factor di atas 0.5 sehingga model telah memenuhi syarat validitas konvergen. Selain dengan melihat nilai loading factor masingmasing indikator, validitas konvergen juga dinilai dari nilai AVE setiap konstruk. Nilai AVE setiap kontruk penelitian ini sudah di atas 0.5. Jadi validitas konvergen dari model penelitian ini sudah memenuhi syarat. Nilai

${ }^{48}$ Chin, WW. (1998). The Partial Least Squares Approach to Structural Equation Modeling. Modern Methods for Business Research, In: G. A. Marcoulides, Ed., Lawrence Erlbaum Associates Publisher, New Jersey, pp. 295-336.

${ }^{49}$ Ghozali, I. Structural Equation Modeling, Metode Alternatif dengan Partial Least Square (PLS), Edisi 4. Semarang: Badan Penerbit Universitas Diponegoro. 2014. 
EVALUASI, 4 (1), Maret 2020, ISSN 2580-3387 (print) |

ISSN 2615-2886 (online)

Homepage : http://e-journal.staima-alhikam.ac.id/index.php/evaluasi

DOI : $\quad:$ http://doi.org/10.32478/evaluasi.v4i1.362

Article type : Original Research Article

loadings, cronbach's alpha, composite reliability dan AVE setiap konstruk selengkapnya dapat dilihat pada tabel 2 berikut:

Tabel 2. Items Loadings, Cronbach's Alpha, Composite Reliability, and Average Variance Extracted (AVE)

\begin{tabular}{|c|c|c|c|c|c|}
\hline Variables & Items & Loadings & $\begin{array}{c}\text { Cronbach's } \\
\text { Alpha }\end{array}$ & $\begin{array}{l}\text { Composite } \\
\text { Reliability }\end{array}$ & AVE \\
\hline \multirow{4}{*}{$\begin{array}{c}\text { Soft Skills } \\
\text { (SS) }\end{array}$} & SS1 & 0.810 & 0.867 & 0.906 & 0.707 \\
\hline & SS2 & 0.856 & & & \\
\hline & SS3 & 0.817 & & & \\
\hline & SS4 & 0.878 & & & \\
\hline \multirow{6}{*}{$\begin{array}{l}\text { Hard Skills } \\
\text { (HS) }\end{array}$} & HS1 & 0.643 & 0.844 & 0.884 & 0.561 \\
\hline & HS2 & 0.713 & & & \\
\hline & HS3 & 0.762 & & & \\
\hline & HS4 & 0.821 & & & \\
\hline & HS5 & 0.792 & & & \\
\hline & HS6 & 0.750 & & & \\
\hline \multirow{5}{*}{$\begin{array}{c}\text { Organizational } \\
\text { culture } \\
\text { (OC) }\end{array}$} & OC1 & 0.847 & 0.896 & 0.924 & 0.708 \\
\hline & OC2 & 0.879 & & & \\
\hline & OC3 & 0.881 & & & \\
\hline & OC4 & 0.818 & & & \\
\hline & OC5 & 0.779 & & & \\
\hline \multirow{7}{*}{$\begin{array}{c}\text { Teacher } \\
\text { Innovation } \\
\text { Capability } \\
\text { (TIC) }\end{array}$} & TIC1 & 0.807 & 0.878 & 0.911 & 0.673 \\
\hline & & & & & \\
\hline & & & & & \\
\hline & TIC 2 & 0.829 & & & \\
\hline & TIC 3 & 0.833 & & & \\
\hline & TIC 4 & 0.793 & & & \\
\hline & TIC 5 & 0.838 & & & \\
\hline
\end{tabular}


EVALUASI, 4 (1), Maret 2020, ISSN 2580-3387 (print) |

ISSN 2615-2886 (online)

Homepage : http://e-journal.staima-alhikam.ac.id/index.php/evaluasi

DOI : : http://doi.org/10.32478/evaluasi.v4i1.362

Article type : Original Research Article

2. Pengujian Validitas Deskriminan

Discriminant validity dilakukan untuk memastikan bahwa setiap konsep dari masing-masing variabel laten berbeda dengan variabel laten lainnya. Model mempunyai discriminant validity yang baik jika nilai kuadrat AVE masing-masing konstruk eksogen (nilai pada diagonal) melebihi korelasi antara konstruk tersebut dengan konstruk lainnya (nilai di bawah diagonal) 50. Hasil pengujian discriminant validity dengan menggunakan nilai kuadrat AVE, yakni dengan melihat Fornell-Larcker Criterion Value diperoleh sebagai berikut:

Tabel 3. Discriminant Validity

\begin{tabular}{ccccc}
\hline Variables & HS & OC & SS & TIC \\
\hline HS & $\mathbf{0 . 7 4 9}$ & & & \\
OC & 0.711 & $\mathbf{0 . 8 4 2}$ & & \\
SS & 0.702 & 0.741 & $\mathbf{0 . 8 4 1}$ & \\
TIC & 0.735 & 0.807 & 0.710 & $\mathbf{0 . 8 2 0}$ \\
\hline
\end{tabular}

Hasil uji validitas deskriminan pada tabel 3 di atas menunjukkan bahwa seluruh konstruk telah memiliki nilai akar kuadrat AVE di atas nilai korelasi dengan konstruk laten lainnya (melalui kriteria Fornell-Larcker) sehingga dapat disimpulkan bahwa model telah memenuhi validitas deskriminan.

\section{Pengujian Reliabilitas Konstruk}

Reliabilitas konstruk dapat dinilai dari nilai cronbach's alpha dan composite reliability dari masing-masing konstruk. Nilai composite reliability dan cronbach's alpha yang disarankan adalah lebih dari 0.7. ${ }^{51}$. Hasil uji reliabilitas pada tabel 2 di atas menunjukkan bahwa seluruh konstruk telah memiliki nilai composite reliability dan cronbach's alpha lebih besar dari 0.7 (> 0.7). Kesimpulannya, seluruh konstruk telah memenuhi reliabilitas yang dipersyaratkan.

\footnotetext{
${ }^{50}$ Ghozali, I. Structural Equation Modeling, Metode Alternatif dengan Partial Least Square $(P L S)$, Edisi 4. Semarang: Badan Penerbit Universitas Diponegoro. 2014.

${ }^{51}$ Idem.
} 
EVALUASI, 4 (1), Maret 2020, ISSN 2580-3387 (print) |

ISSN 2615-2886 (online)

Homepage : http://e-journal.staima-alhikam.ac.id/index.php/evaluasi

DOI : $\quad:$ http://doi.org/10.32478/evaluasi.v4i1.362

Article type : Original Research Article

\section{Pengujian Hipotesis}

Pengujian hipotesis dalam PLS disebut juga sebagai uji inner model. Uji ini meliputi uji signifikansi pengaruh langsung dan tidak langsung serta pengukuran besarnya pengaruh variabel eksogen terhadap variabel endogen. Untuk mengetahui pengaruh tacit dan hard skills sharing terhadap organizational culture dan teacher innovation capability dibutuhkan uji pengaruh langsung. Uji pengaruh langsung dilakukan dengan menggunakan uji t-statistik dalam model analisis partial least squared (PLS) dengan menggunakan bantuan software SmartPLS 3.0. Dengan teknik boothstrapping, diperoleh nilai $R$ Square dan nilai uji signifikansi sebagaimana tabel di bawah ini:

Tabel 4. Nilai $R$ Square

\begin{tabular}{ccc}
\hline & R Square & R Square Adjusted \\
\hline TIC & 0.711 & 0.710 \\
OC & 0.620 & 0.621 \\
\hline
\end{tabular}


EVALUASI, 4 (1), Maret 2020, ISSN 2580-3387 (print) |

ISSN 2615-2886 (online)

Homepage : http://e-journal.staima-alhikam.ac.id/index.php/evaluasi

DOI : : http://doi.org/10.32478/evaluasi.v4i1.362

Article type : Original Research Article

Tabel 5. Hypotheses Testing

\begin{tabular}{clccccc}
\hline Hypotheses & Relationship & Beta & SE & $\begin{array}{c}\text { T } \\
\text { Statistics }\end{array}$ & $\begin{array}{c}\text { V- } \\
\text { Values }\end{array}$ & Decision \\
\hline H1 & HS -> TIC & 0.278 & 0.045 & 6.128 & 0.000 & Supported \\
H2 & SS -> TIC & 0.141 & 0.040 & 3.474 & 0.001 & Supported \\
H3 & HS -> OC & 0.377 & 0.038 & 9.943 & 0.000 & Supported \\
H4 & SS -> OC & 0.476 & 0.035 & 13.449 & 0.000 & Supported \\
H5 & OC -> TIC & 0.505 & 0.047 & 10.695 & 0.000 & Supported \\
H6 & HS -> OC -> TIC & 0.190 & 0.030 & 6.400 & 0.000 & Supported \\
H7 & SS -> OC -> TIC & 0.240 & 0.026 & 9.324 & 0.000 & Supported
\end{tabular}

Berdasarkan Tabel 4 di atas, nilai $R$ Square OC sebesar 0.620 yang berarti bahwa variabel organizational culture (OC) mampu dijelaskan oleh variabel hard skills (HS) dan soft skills (SS) sebesar 62.0\%, sedangkan sisanya sebesar $38.0 \%$ dijelaskan oleh variabel lain yang tidak dibahas dalam penelitian ini. Sementara itu, nilai $R$ Square teacher innovation capability (TIC) sebesar 0.711 yang berarti bahwa variabel teacher innovation capability mampu dijelaskan variabel hard skills, soft skills dan organizational culture sebesar $71.1 \%$, sedangkan sisanya sebesar $29.9 \%$ dijelaskan oleh variabel lain yang tidak dibahas dalam penelitian ini. Sedangkan Tabel 5 menampilkan $T$ Statistics dan $P$-Values yang menunjukkan pengaruh antar variable penelitian yang telah disebutkan. 
EVALUASI, 4 (1), Maret 2020, ISSN 2580-3387 (print) |

ISSN 2615-2886 (online)

Homepage : http://e-journal.staima-alhikam.ac.id/index.php/evaluasi

DOI : : http://doi.org/10.32478/evaluasi.v4i1.362

Article type : Original Research Article

\section{Diskusi}

Berdasarkan hasil penelitian, dapat diambil kesimpulan bahwa hard skills sharing memberikan pengaruh positif dan signifikan terhadap teacher innovation capability. Baik secara langsung maupun melalui mediasi organizational culture. Artinya bahwa semakin positif hard skills dimiliki oleh guru, maka akan semakin meningkat pula pula teacher innovation capability individu guru di lembaga pendidikan sekolah. Temuan ini sejalan dengan penelitian terdahulu pada organisasi bisnis, yakni Perez-Luno et al ${ }^{52}$, Terhorst et al ${ }^{53}$, Boadu et al ${ }^{54}$, Che et al ${ }^{55}$. Demikian juga soft skills berpengaruh positif dan signifikan terhadap teacher innovation capability, Baik secara langsung maupun melalui mediasi organizational culture. Artinya bahwa semakin positif soft skills dimiliki oleh guru, maka akan semakin meningkat pula pula teacher innovation capability individu guru. Artinya, organizational culture menjadi antara soft skills guru dan teacher innovation capability.

Hasil penelitian ini juga menyimpulkan bahwa hard skills dan soft skills berpengaruh positif dan signifikan terhadap organizational culture. Artinya adalah semakin baik hard skills dan soft skills yang dikuasi seorang guru, maka semakin positif pembentukan dan pengembangan organizational culture di lembaga pendidikan sekolah. Hal ini sejalan juga dengan kesimpulan penelitian Qi \& Chau ${ }^{56}$ pada organisasi bisnis. Hal ini mengisyaratkan bahwa sumber

\footnotetext{
${ }^{52}$ Pérez-Luño, A., Alegre, J., \& Valle-Cabrera, R. (2018). The role of soft skills in connecting knowledge exchange and combination with innovation. Technology Analysis \& Strategic Management, 1-13. doi:10.1080/09537325.2018.1492712

${ }^{53}$ Terhorst, A., Lusher, D., Bolton, D., Elsum, I., \& Wang, P. (2018). Soft skills Sharing in Open Innovation Projects. Project Management Journal, 49(4), 5-19. doi: $10.1177 / 8756972818781628$

${ }^{54}$ Boadu, F., Xie, Y., Du, Y.-F., \& Dwomo-Fokuo, E. (2018). MNEs Subsidiary Training and Development and Firm Innovative Performance: The Moderating Effects of Tacit and Hard skills Received from Headquarters. Sustainability, 10(11), 4208. doi:10.3390/su10114208

${ }^{55}$ Che, T., Wu, Z., Wang, Y. and Yang, R. (2019), "Impacts of knowledge sourcing on employee innovation: the moderating effect of information transparency", Journal of Knowledge Management, Vol. 23 No. 2, pp. 221-239. https://doi.org/10.1108/JKM-112017-0554

56 Qi, C. and Chau, P.Y.K. (2018) Will enterprise social networking systems promote knowledge management and organizational culture? An empirical study, Journal of
} 
EVALUASI, 4 (1), Maret 2020, ISSN 2580-3387 (print) |

ISSN 2615-2886 (online)

Homepage : http://e-journal.staima-alhikam.ac.id/index.php/evaluasi

DOI : : http://doi.org/10.32478/evaluasi.v4i1.362

Article type : Original Research Article

daya yang paling langka dan paling berharga di era digital bukanlah guru biasa dan mediocre, melainkan guru yang dapat menciptakan ide dan inovasi baru ${ }^{57}$. Guru yang memainkan peran kunci dalam memproduksi dan menggunakan kembali pengetahuan dan kekayaan intelektualnya melalui pendidikan dan pengajaran ${ }^{58}$ (. Karena alasan inilah, kelangkaan guru yang memiliki hard skills dan soft skills yang memadai dan terampil bisa melumpuhkan daya inovasi, competitiveness, pertumbuhan dan fleksibilitas lembaga pendidikan sekolah. Tak ayal, di masa depan, bakat dan respon guru sekolah dalam meningkatkan hard skills dan soft skills akan menjadi faktor penting masa depan pendidikan bangsa. Guru sekolah dengan keterampilan dan inovasi akan menjadi barang mewah modal dan instrument peradaban.

Beberapa penelitian menyimpulkan bahwa soft skills lebih banyak berpengaruh kepada inovasi daripada hard skills ${ }^{59}$. Namun pada penelitian ini menunjukkan hard skills lebih besar pengaruhnya terhadap teacher innovation capability. Kemungkinan rasionalnya adalah karena responden penelitian ada di kota-kota besar, yakni di Jakarta dan Tangerang.

Berdasarkan temuan penelitian ini, fakta menyimpulkan bahwa organizational culture berpengaruh positif dan signifikan terhadap teacher innovation capability. Organizational culture juga memediasi pengaruh hard skills dan soft skills terhadap teacher innovation capability. Hal ini sesuai dengan kesimpulan Martinez-Costa ${ }^{60}$. Penelitian ini juga menyimpulkan bahwa lembaga pendidikan sekolah bisa mengelola pengalaman masa lalu untuk dikombinasikan dengan hard skills dan soft skills yang dimiliki guru saat

\footnotetext{
Organizational Computing and Electronic Commerce, 28:1, 31-57, DOI: 10.1080/10919392.2018.1407081

${ }^{57}$ Xu, M., David, J. M., \& Kim, S. H. (2018). The Fourth Industrial Revolution: Opportunities and Challenges. International Journal of Financial Research, 9(2), 90. doi:10.5430/ijfr.v9n2p90

${ }^{58}$ Al-Kurdi, O., El-Haddadeh, R., \& Eldabi, T. (2018). Knowledge sharing in higher education institutions: a systematic review. Journal of Enterprise Information Management, 31(2), 226-246. doi:10.1108/jeim-09-2017-0129

${ }^{59}$ Ibrahim, R., Boerhannoeddin, A. and Bakare, K. (2017), "The effect of soft skills and training methodology on employee performance", European Journal of Training and Development, Vol. 41 No. 4, pp. 388-406. https://doi.org/10.1108/EJTD-08-2016-0066

${ }^{60}$ Martínez-Costa, M., Jiménez-Jiménez, D., \& Dine Rabeh, H. A. (2018). The effect of organisational learning on interorganisational collaborations in innovation: an empirical study in SMEs. Knowledge Management Research \& Practice, 1-14. doi:10.1080/14778238.2018.1538601
} 
EVALUASI, 4 (1), Maret 2020, ISSN 2580-3387 (print) |

ISSN 2615-2886 (online)

Homepage : http://e-journal.staima-alhikam.ac.id/index.php/evaluasi

DOI : : http://doi.org/10.32478/evaluasi.v4i1.362

Article type : Original Research Article

ini. Intinya, organizational culture mampu memberikan kondisi positif dalam proses penciptaan pengetahuan di era education 4.0 saat ini.

\section{Kesimpulan}

Guna menambahkan peran soft skills sebagai predictor teacher innovation capability, sekolah perlu memberikan otonomi dan keluasan untuk berbagi pengetahuan pada para guru. Oleh karena itu, sekolah perlu menciptakan organizational culture sebagai environtment positif yang memacu kompetensi dan engagement individu guru pada lembaga pendidikan sekolah. Sesungguhnya knowledge management akan berjalan efektif di dalam lembaga pendidikan sekolah jika individual performance setiap guru dalam kondisi bagus.

Para peneliti terus mempelajari tentang pengetahuan sebagai sumber daya sekolah yang penting. Bisa dikatakan bahwa keterampilan, baik hard skills maupun soft skills mampu meningkatkan kinerja sekolah secara signifikan. Organizational culture mengubah pengetahuan individu menjadi pengetahuan sekolah. Penelitian ini menyimpulkan bahwa organizational culture berperan sebagai katalisator dari proses penciptaan pengetahuan di antara guru di sekolah. Karena sejatinya, guru lah yang mengemban kewajiban mempersiapkan anak didik mereka untuk belajar dan bekerja dalam masyarakat pengetahuan ini.

\section{Implikasi Manajerial}

Berdasarkan kesimpulan penelitian ini, manajemen lembaga pendidikan sekolah perlu membangun keterlibatan maksimal seluruh guru untuk terus menerus meningkatkan hard skills dan soft skills mereka. Pelatihan guru di setiap bagian sekolah merupakan kebutuhan dengan tingkat intensitas, konten dan konteks yang disesuaikan dengan key performance indicator masing-masing guru. Intinya, team learning behavior 
EVALUASI, 4 (1), Maret 2020, ISSN 2580-3387 (print) |

ISSN 2615-2886 (online)

Homepage : http://e-journal.staima-alhikam.ac.id/index.php/evaluasi

DOI : : http://doi.org/10.32478/evaluasi.v4i1.362

Article type : Original Research Article

yang diciptakan di lingkungan sekolah akan menjadi pendorong inovasi guru 61.

Proses meningkatkan keterampilan untuk membangun teacher innovation capability lembaga pendidikan sekolah hendaknya tidak hanya terbatas pada proses internal sekolah. Tetapi, manajemen sekolah perlu meluaskan proses membangun inovasi ini melalui upaya menyerap, mengartikulasi, memanfaatkan dan mengelola pengetahuan yang bersumber dari mitra eksternal sekolah seperti orang tua siswa, pemerintah, masyarakat, dan lembaga pendidikan lainnya. Manajemen sekolah bisa mengaktifkan learning from others ketika menugaskan gurunya untuk menghadiri training, seminar, workshop, kunjungan ke sekolah lain, bertemu dengan komite sekolah dan mitra strategis lainnya. Karena pengetahuan eksternal, seperti yang berasal dari trainer, coach, orang tua siswa, pemerintah, masyarakat, dan lembaga pendidikan lainnya mendukung daya teacher innovation capability lembaga pendidikan sekolah.

Selain itu, komitmen pembelajaran dan kesungguhan untuk terlibat dalam mengelola lingkungan pembelajaran menjadi hal yang perlu diperhatikan. Karena lembaga pendidikan sekolah bisa menjadi organizational culture tatkala seluruh civitas lembaga pendidikan sekolah merasa menikmati proses pembelajaran ini. Learning process menjadi budaya sekolah yang mendorong inovasi. Faktor kunci organizational culture adalah kepercayaan, komunikasi terbuka, keterlibatan yang tinggi, adanya tantangan industry, dan suasana kerja yang kreatif. Tugas manajemen sekolah adalah memfasilitasi terpenuhinya factor-faktor kunci tersebut.

\section{Keterbatasan Penelitian}

Penelitian ini memiliki beberapa keterbatasan. Pertama, penelitian ini menganalisis pengaruh hard skills dan soft skills terhadap teacher innovation capability guru, baik secara langsung maupun secara tidak langsung melalui variable organizational culture. Karena mungkin ada beberapa variable lain yang mempengaruhi teacher innovation capability,

${ }^{61}$ Widmann, A. and Mulder, R. (2018), "Team learning behaviours and innovative work behaviour in work teams", European Journal of Innovation Management, Vol. 21 No. 3, pp. 501-520. https://doi.org/10.1108/EJIM-12-2017-0194 
EVALUASI, 4 (1), Maret 2020, ISSN 2580-3387 (print) |

ISSN 2615-2886 (online)

Homepage : http://e-journal.staima-alhikam.ac.id/index.php/evaluasi

DOI : : http://doi.org/10.32478/evaluasi.v4i1.362

Article type : Original Research Article

misal: knowledge management, leadership kepala sekolah, dan lain-lain. Penulis sangat menyarankan untuk menemukan, mengeksplorasi dan menganalisisnya. Kedua, penelitian ini dilakukan di lingkungan lembaga pendidikan sekolah Islam dan mungkin tidak dapat digeneralisasi untuk industry lain. Oleh karena itu sangat disarankan dilakukan penelitian lebih lanjut tentang topic ini di industry lain.

\section{Daftar Pustaka}

Al-Kurdi, O., El-Haddadeh, R., \& Eldabi, T. (2018). Knowledge sharing in higher education institutions: a systematic review. Journal of Enterprise Information Management, 31(2), 226-246. doi:10.1108/jeim-09-20170129

Asbari, M., Santoso, P., \& Purwanto, A. (2019). Pengaruh Iklim Organisasi dan Kepemimpinan Transformasional Terhadap Produktivitas Kerja Inovatif Pada Industri Manufaktur di Pati Jawa Tengah. Jurnal Produktivitas Universitas Muhammadiyah Pontianak: 7(1 2020): 62-69. doi: 10.29406/jpr.v7i1.1797

Azim, S., Gale, A., Lawlor-Wright, T., Kirkham, R., Khan, A., \& Alam, M. (2010). The importance of soft skills in complex projects. International Journal of Managing Projects in Business, 3(3), 387-401. doi:10.1108/17538371011056048

Bani-Melhem, S., Zeffane, R. and Albaity, M. (2018), "Determinants of employees' innovative behavior", International Journal of Contemporary Hospitality Management, Vol. 30 No. 3, pp. 1601-1620. https://doi.org/10.1108/IJCHM-02-2017-0079

Boadu, F., Xie, Y., Du, Y.-F., \& Dwomo-Fokuo, E. (2018). MNEs Subsidiary Training and Development and Firm Innovative Performance: The Moderating Effects of Tacit and Hard skills Received from Headquarters. Sustainability, 10(11), 4208. doi:10.3390/su10114208

Borrego, G., Morán, A. L., Palacio, R. R., Vizcaíno, A., \& García, F. O. (2019). Towards a reduction in architectural knowledge vaporization during agile global software development. Information and Software Technology. doi:10.1016/j.infsof.2019.04.008 
EVALUASI, 4 (1), Maret 2020, ISSN 2580-3387 (print) |

ISSN 2615-2886 (online)

Homepage : http://e-journal.staima-alhikam.ac.id/index.php/evaluasi

DOI

: http://doi.org/10.32478/evaluasi.v4i1.362

Article type : Original Research Article

Boske, C. and Osanloo, A. (2015), "Conclusion - Preparing all School Community Leaders to Live their Work", Living the Work: Promoting Social Justice and Equity Work in Schools around the World (Advances in Educational Administration, Vol. 23), Emerald Group Publishing Limited, pp. 405-426. https://doi.org/10.1108/S1479-366020140000023032

Chang, C. and Lin, T. (2015), "The role of organizational culture in the knowledge management process", Journal of Knowledge Management, Vol. 19 No. 3, pp. 433-455. https://doi.org/10.1108/JKM-08-2014-0353

Che, T., Wu, Z., Wang, Y. and Yang, R. (2019), "Impacts of knowledge sourcing on employee innovation: the moderating effect of information transparency", Journal of Knowledge Management, Vol. 23 No. 2, pp. 221-239. https://doi.org/10.1108/JKM-11-2017-0554

Chin, WW. (1998). The Partial Least Squares Approach to Structural Equation Modeling. Modern Methods for Business Research, In: G. A. Marcoulides, Ed., Lawrence Erlbaum Associates Publisher, New Jersey, pp. 295-336.

Culot, G., Orzes, G., \& Sartor, M. (2019). Integration and scale in the context of Industry 4.0: the evolving shapes of manufacturing value chains. IEEE Engineering Management Review, 1-1. doi:10.1109/emr.2019.2900652

Deranek, K., McLeod, A., \& Schmidt, E. (2017). ERP Simulation Effects on Knowledge and Attitudes of Experienced Users. Journal of Computer Information Systems, 1-11. doi:10.1080/08874417.2017.1373610

Ganguly, A., Talukdar, A. and Chatterjee, D. (2019), "Evaluating the role of social capital, soft skills sharing, knowledge quality and reciprocity in determining teacher innovation capability of an organization", Journal of Knowledge Management, Vol. 23 No. 6, pp. 1105-1135. https://doi.org/10.1108/JKM-03-2018-0190

Ghozali, I. Structural Equation Modeling, Metode Alternatif dengan Partial Least Square (PLS), Edisi 4. Semarang: Badan Penerbit Universitas Diponegoro. 2014.

Gunasekaran, A., Subramanian, N., \& Ngai, E. (2018). Quality Management in the 21st Century Enterprises: Research pathway towards Industry 4.0. International Journal of Production Economics. doi:10.1016/j.ijpe.2018.09.005 
EVALUASI, 4 (1), Maret 2020, ISSN 2580-3387 (print) |

ISSN 2615-2886 (online)

Homepage : http://e-journal.staima-alhikam.ac.id/index.php/evaluasi

DOI : : http://doi.org/10.32478/evaluasi.v4i1.362

Article type : Original Research Article

Haamann, T., \& Basten, D. (2018). The role of information technology in bridging the knowing-doing gap: an exploratory case study on knowledge application. Journal of Knowledge Management. doi:10.1108/jkm-012018-0030

Hendarman, A. F., \& Cantner, U. (2017). Soft skills, hard skills, and individual innovativeness. Eurasian Business Review, 8(2), 139-169. doi:10.1007/s40821-017-0076-6

Holford, W.D. (2018). The future of human creative knowledge work within the digital economy. Futures. doi:10.1016/j.futures.2018.10.002

Honeycutt, Jerry. (2000). Knowledge Management Strategies: Strategi Manajemen Pengetahuan. Jakarta : PT. Alex Media Komputindo

Hussain, S. T., Lei, S., Akram, T., Haider, M. J., Hussain, S. H., \& Ali, M. (2018). Kurt Lewin's change model: A critical review of the role of leadership and employee involvement in organizational change. Journal of Innovation \& Knowledge, 3(3), 123-127. doi:10.1016/j.jik.2016.07.002

Ibrahim, R., Boerhannoeddin, A. and Bakare, K. (2017), "The effect of soft skills and training methodology on employee performance", European Journal of Training and Development, Vol. 41 No. 4, pp. 388-406. https://doi.org/10.1108/EJTD-08-2016-0066

Imran, M., Ilyas, M., Aslam, U. and Fatima, T. (2018), "Knowledge processes and firm performance: the mediating effect of employee creativity", Journal of Organizational Change Management, Vol. 31 No. 3, pp. 512531. https://doi.org/10.1108/JOCM-10-2016-0202

Jiménez-Jiménez, D., \& Sanz-Valle, R. (2011). Innovation, organizational culture, and performance. Journal of Business Research, 64(4), 408-417. doi:10.1016/j.jbusres.2010.09.010

Kim, N. and Shim, C. (2018). Social capital, knowledge sharing and innovation of small- and medium-sized enterprises in a tourism cluster. International Journal of Contemporary Hospitality Management, Vol. 30 No. 6, pp. 2417-2437. https://doi.org/10.1108/IJCHM-07-2016-0392

Klaeijsen, A., Vermeulen, M., \& Martens, R. (2017). Teachers' Innovative Behaviour: The Importance of Basic Psychological Need Satisfaction, Intrinsic Motivation, and Occupational Self-Efficacy. Scandinavian Journal 
EVALUASI, 4 (1), Maret 2020, ISSN 2580-3387 (print) |

ISSN 2615-2886 (online)

Homepage : http://e-journal.staima-alhikam.ac.id/index.php/evaluasi

DOI : : http://doi.org/10.32478/evaluasi.v4i1.362

Article type : Original Research Article

of Educational Research, 62(5), 769-782. doi:10.1080/00313831.2017.1306803

Lecat, A., Beausaert, S. \& Raemdonck, I. (2018). On the Relation Between Teachers' (In)formal Learning and Innovative Working Behavior: the Mediating Role of Employability. Vocations and Learning 11, 529-554. doi:10.1007/s12186-018-9199-x

Lee, H. and Choi, B. (2003). Knowledge Management Enablers, Processes, and Organizational Performance: An Integrative View and Empirical Examination. (2003). Journal of Management Information Systems, 20(1), 179-228. doi:10.1080/07421222.2003.11045756

Lee, Peter. (2019). Soft skills and University-Industry Technology Transfer. Research Handbook on Intellectual Property and Technology Transfer (2019, Forthcoming); UC Davis Legal Studies Research Paper Forthcoming. doi: http://dx.doi.org/10.2139/ssrn.3417933

Li, M., Liu, H. and Zhou, J. (2018), "G-SECl model-based knowledge creation for CoPS innovation: the role of grey knowledge", Journal of Knowledge Management, Vol. 22 No. 4, pp. 887-911. https://doi.org/10.1108/JKM10-2016-0458

Lombardi, R. (2019). Knowledge transfer and organizational performance and business process: past, present and future researches. Business Process Management Journal, 25(1), 2-9. doi:10.1108/bpmj-02-2019-368

Ma, Q., Mayfield, M. and Mayfield, J. (2018), "Keep them on-board! How organizations can develop employee embeddedness to increase employee retention", Development and Learning in Organizations, Vol. 32 No. 4, pp. 5-9. https://doi.org/10.1108/DLO-11-2017-0094

Malik, A. (2019). Creating competitive advantage through source basic capital strategic humanity in the industrial age 4.0. International Research Journal of Advanced Engineering and Science 4(1): 209-215. www.irjaes.com/pdf/V4N1Y18-IRJAES/IRJAES-V4N1P195Y19.pdf

Martínez-Costa, M., Jiménez-Jiménez, D., \& Dine Rabeh, H. A. (2018). The effect of organisational learning on interorganisational collaborations in innovation: an empirical study in SMEs. Knowledge Management Research \& Practice, 1-14. doi:10.1080/14778238.2018.1538601 
EVALUASI, 4 (1), Maret 2020, ISSN 2580-3387 (print) |

ISSN 2615-2886 (online)

Homepage : http://e-journal.staima-alhikam.ac.id/index.php/evaluasi

DOI : : http://doi.org/10.32478/evaluasi.v4i1.362

Article type : Original Research Article

Mohajan, Haradhan (2016): Sharing of Soft skills in Organizations: A Review. Published in: American Journal of Computer Science and Engineering, Vol. 3, No. 2 (1 July 2016): pp. 6-19. https://mpra.ub.unimuenchen.de/id/eprint/82958

Muqowim (2012). Pengembangan Soft Skills Guru. Yogyakarta: Pedagogia

Muthuveloo, R., Shanmugam, N., \& Teoh, A. P. (2017). The impact of soft skills management on organizational performance: Evidence from Malaysia. Asia Pacific Management Review, 22(4), 192-201. doi:10.1016/j.apmrv.2017.07.010

Naqshbandi, M., Tabche, I. and Choudhary, N. (2019), Managing open innovation: The roles of empowering leadership and employee involvement climate, Management Decision, Vol. 57 No. 3, pp. 703-723. https://doi.org/10.1108/MD-07-2017-0660

Nouri, B.A., \& Ghorbani, R. (2017). The Effect of Knowledge Management on Organizational Innovation with the Mediating Role of Organizational culture (Case Study : Agricultural Bank in Iran). Journal of Applied Economics and Business Research JAEBR, 7(3): 194-211. https://www.semanticscholar.org/paper/The-Effect-of-KnowledgeManagement-on-Innovation-of-NouriGhorbani/fb9eb1df37e4a47c9b3ac2bbf0bbc4f4907b80a2

Nugroho, M. (2018), "The effects of collaborative cultures and knowledge sharing on organizational culture", Journal of Organizational Change Management, Vol. 31 No. 5, pp. 1138-1152. https://doi.org/10.1108/JOCM-10-2017-0385

Pérez-Luño, A., Alegre, J., \& Valle-Cabrera, R. (2018). The role of soft skills in connecting knowledge exchange and combination with innovation. Technology Analysis \& Strategic Management, 1-13. doi:10.1080/09537325.2018.1492712

Pérez-Luño, A., Alegre, J., \& Valle-Cabrera, R. (2018). The role of soft skills in connecting knowledge exchange and combination with innovation. Technology Analysis \& Strategic Management, 1-13. doi:10.1080/09537325.2018.1492712

Polanyi, M. (1966). The Tacit dimension. New York: Doubleday \& Co. 
EVALUASI, 4 (1), Maret 2020, ISSN 2580-3387 (print) |

ISSN 2615-2886 (online)

Homepage : http://e-journal.staima-alhikam.ac.id/index.php/evaluasi

DOI : : http://doi.org/10.32478/evaluasi.v4i1.362

Article type : Original Research Article

Qi, C. and Chau, P.Y.K. (2018) Will enterprise social networking systems promote knowledge management and organizational culture? An empirical study, Journal of Organizational Computing and Electronic Commerce, 28:1, 31-57, DOI: 10.1080/10919392.2018.1407081

Qi, C. and Chau, P.Y.K. (2018) Will enterprise social networking systems promote knowledge management and organizational culture? An empirical study, Journal of Organizational Computing and Electronic Commerce, 28:1, 31-57, DOI: 10.1080/10919392.2018.1407081

Rainsbury, E., Hodges, D., Burchell, N. \& Lay, M. C. (2002). Ranking workplace competencies: Student and graduate perceptions. Asia-Pacific Journal of Cooperative Education, 3(2), 8-18. https://hdl.handle.net/10289/3219

Rainsbury, E., Hodges, D., Burchell, N. \& Lay, M. C. (2002). Ranking workplace competencies: Student and graduate perceptions. Asia-Pacific Journal of Cooperative Education, 3(2), 8-18. https://hdl.handle.net/10289/3219

Samsir, S. (2018), The effect of leadership orientation on innovation and its relationship with competitive advantages of small and medium enterprises in Indonesia, International Journal of Law and Management, Vol. 60 No. 2, pp. 530-542. https://doi.org/10.1108/IJLMA-01-2017-0005

Starbuck, W. (2017), "Organizational culture and unlearning", The Learning Organization, Vol. 24 No. 1, pp. 30-38. https://doi.org/10.1108/TLO-112016-0073

Stewart, C., Schiavon, L.M. and Bellotto, M.L. (2017) Knowledge, nutrition and coaching pedagogy: a perspective from female Brazilian Olympic gymnasts, Sport, Education and Society, 22(4): 511-527, DOI: $\underline{10.1080 / 13573322.2015 .1046428}$

Terhorst, A., Lusher, D., Bolton, D., Elsum, I., \& Wang, P. (2018). Soft skills Sharing in Open Innovation Projects. Project Management Journal, 49(4), 5-19. doi:10.1177/8756972818781628

Wang, C., Chen, M. and Chang, C. (2019), "The double-edged effect of knowledge search on innovation generations", European Journal of Innovation Management, Vol. ahead-of-print No. ahead-of-print. https://doi.org/10.1108/EJIM-04-2018-0072 
EVALUASI, 4 (1), Maret 2020, ISSN 2580-3387 (print) |

ISSN 2615-2886 (online)

Homepage : http://e-journal.staima-alhikam.ac.id/index.php/evaluasi

DOI : : http://doi.org/10.32478/evaluasi.v4i1.362

Article type : Original Research Article

Wetzel R., Tint B. (2019) Using Applied Improvisation for Organizational culture in the Red Cross Red Crescent Climate Centre. In: Antonacopoulou E., Taylor S. (eds) Sensuous Learning for Practical Judgment in Professional Practice. Palgrave Studies in Business, Arts and Humanities. Palgrave Macmillan, Cham. https://doi.org/10.1007/978-3-319-99049$\underline{13}$

Widmann, A. and Mulder, R. (2018), "Team learning behaviours and innovative work behaviour in work teams", European Journal of Innovation Management, Vol. 21 No. 3, pp. 501-520. https://doi.org/10.1108/EJIM-12-2017-0194

Widoyoko, E.P. (2009). Evaluasi Program Pembelajaran Panduan Praktis bagi Pendidik dan Calon Pendidik. Yogyakarta: Pustaka

Xu, M., David, J. M., \& Kim, S. H. (2018). The Fourth Industrial Revolution: Opportunities and Challenges. International Journal of Financial Research, 9(2), 90. doi:10.5430/ijfr.v9n2p90

Yang, Z., Nguyen, V. and Le, P. (2018), Knowledge sharing serves as a mediator between collaborative culture and teacher innovation capability: an empirical research, Journal of Business \& Industrial Marketing, Vol. 33 No. 7, pp. 958-969. https://doi.org/10.1108/JBIM-102017-0245

Zambon, I., Cecchini, M., Egidi, G., Saporito, M. G., \& Colantoni, A. (2019). Revolution 4.0: Industry vs. Agriculture in a Future Development for SMEs. Processes, 7(1), 36. doi:10.3390/pr7010036

Zhu, Q., Krikke, H. and Caniëls, M. (2018), Supply chain integration: value creation through managing inter-organizational culture. International Journal of Operations \& Production Management. 38(1): 211-229. https://doi.org/10.1108/IJOPM-06-2015-0372

Zouaghi, F., Sánchez, M., \& Martínez, M. G. (2018). Did the global financial crisis impact firms' innovation performance? The role of internal and external knowledge capabilities in high and low tech industries. Technological Forecasting and Social Change. 132: 92-104. doi:10.1016/j.techfore.2018.01.011 